Discussion Paper No. 04-35

\title{
Integrated Financial Supervision in Germany
}

Martin Schüler

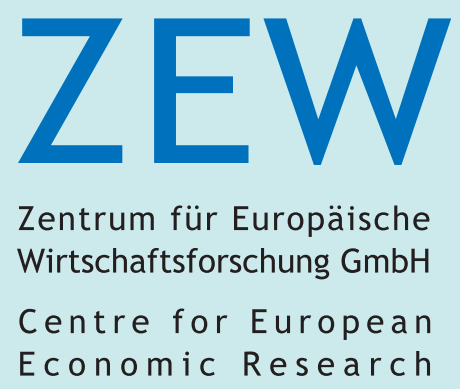


Discussion Paper No. 04-35

\title{
Integrated Financial Supervision in Germany
}

\author{
Martin Schüler
}

Download this ZEW Discussion Paper from our ftp server:

ftp://ftp.zew.de/pub/zew-docs/dp/dp0435.pdf

Die Discussion Papers dienen einer möglichst schnellen Verbreitung von neueren Forschungsarbeiten des ZEW. Die Beiträge liegen in alleiniger Verantwortung der Autoren und stellen nicht notwendigerweise die Meinung des ZEW dar.

Discussion Papers are intended to make results of ZEW research promptly available to other economists in order to encourage discussion and suggestions for revisions. The authors are solely responsible for the contents which do not necessarily represent the opinion of the ZEW. 


\section{Non-Technical Summary}

On January 25, 2001 the finance minister of Germany, Hans Eichel, announced a "radical shake-up of the German financial supervision" (Engelen, 2001). He declared the establishment of an integrated financial supervisory authority. 15 month later, on May 1, 2002 the Bundesanstalt für Finanzdienstleistungsaufsicht (BaFin) started operating. Germany thereby followed the general trend towards integrated financial supervision.

The main reason for the creation of single financial services supervisors is the growing integration of financial sectors leading to the blurring of boundaries between banking, insurance and securities activities. One aspect in this context is the growing importance of financial conglomerates, the acquisition of Dresdner Bank by Allianz being a paramount example. Another aspect is that channels of distribution of financial products are no longer as specialised as they used to be. Banks use their branch network to sell, e.g., insurance products or even non-financial products. Moreover, one can observe a blurring of boundaries between financial products. These financial market developments are often labelled with the notions bancassurance and Allfinanz.

The aim of this paper is to analyse the development of Allfinanz, and hence the driving forces for the creation of the single supervisory authority in Germany. Moreover, BaFin's tasks and structure are discussed, as well as the involvement of the German Bundesbank in financial supervision. 


\title{
Integrated Financial Supervision in Germany
}

\author{
Martin Schüler*
}

\author{
ZEW Mannheim
}

May 2004

\begin{abstract}
With the establishment of the Bundesanstalt für Finanzdienstleistungsaufsicht (BaFin) in May 2002 Germany followed the trend towards integrated financial supervision. The main reason for unification of supervision is the growing integration of financial sectors leading to the blurring of boundaries between banking, insurance and securities activities. The aim of this paper is to analyse the development of Allfinanz, and hence the driving forces for the creation of the single supervisory authority in Germany. Moreover, BaFin's tasks and structure are discussed.
\end{abstract}

JEL-Classification: G20, G38

Keywords: financial supervision, integrated supervision, Germany

\footnotetext{
* Centre for European Economic Research (ZEW); P.O. Box 103443, D-68034 Mannheim, Germany, Phone: +49/621/1235-148, Fax: +49/621/1235-223, E-mail: schueler@zew.de. The author is also affiliated to Otto Beisheim Graduate School of Management WHU Koblenz.
}

Acknowledgement: I am indebted to Friedrich Heinemann, Michael Schröder and Michael Wolgast for helpful comments and suggestions. 


\section{Introduction}

On January 25, 2001 the finance minister of Germany, Hans Eichel, announced a "radical shake-up of the German financial supervision" (Engelen, 2001). He declared the establishment of an integrated financial supervisory authority. 15 month later, on May 1, 2002 the Bundesanstalt für Finanzdienstleistungsaufsicht (BaFin) started operating. BaFin consolidated the hitherto separated supervisory agencies for banking (Bundesaufsichtsamt für das Kreditwesen - BAKred), insurance (Bundesaufsichtsamt für das Versicherungswesen - BAV) and securities (Bundesaufsichtsamt für den Wertpapierhandel - BAWe). Germany thereby followed the general trend towards integrated financial supervision.

One reason for the creation of single financial services supervisors is the growing integration of the financial sector. The distinctions between banking, insurance and securities markets become increasingly blurred. One aspect in this context is the growing importance of financial conglomerates, the acquisition of Dresdner Bank by Allianz being a paramount example. Another aspect is that channels of distribution of financial products are no longer as specialised as they used to be. Banks use their branch network to sell, e.g., insurance products or even non-financial products. Moreover, one can observe a blurring of boundaries between financial products. These financial market developments are often labelled with the notions bancassurance and Allfinanz.

The aim of this paper is to discuss the development of Allfinanz and the creation of the integrated financial regulator ${ }^{1}$ in Germany. The next section gives the rationale for the reform of financial supervision in Germany. Section 3 describes the importance of Allfinanz for the German financial sector and evaluates the resulting need for integrating supervisory functions. Section 4 deals with the formation, organisation and tasks of the new integrated supervisor BaFin. The involvement in financial supervision of the German central bank, the Bundesbank, is discussed in Section 5. Finally, Section 6 concludes.

\section{The Rationale for Integrated Supervision in Germany}

The arguments in favour of unification of supervisory functions are numerous. ${ }^{2}$ Well-established arguments include the following: Unification allows the realisation of cost savings through economies of scale; the supervisory structure

\footnotetext{
${ }^{1}$ Note that throughout the paper the notions supervisor and regulator are used interchangeable as is common practise in the literature.

${ }^{2}$ For a full discussion of the arguments for as well as against integrated supervision, see Briault (1999, 2002), Abrams and Taylor (2000, 2002), and Luna Martínez and Rose (2003).
} 
should reflect the integration of financial sectors; regulatory arbitrage can be avoided; accountability is enhanced; and international co-operation is fostered.

Although "there is a strong consensus on the benefits of integrated supervision" (Taylor and Fleming, 1999b: 43), there are also strong arguments against the creation of an integrated supervisor. These include the following concerns: Unification could lead to lack of clarity; an integrated agency could suffer from diseconomies of scale; concentration of power could vitiate democratic policies; and moral hazard concerns could be extended across the whole financial sector.

The aim of this paper is not to weigh the advantages and disadvantages of establishing a single financial regulator. Instead we focus on the specific German situation and the motivation to create a single supervisory agency there.

\section{The German Situation}

In Germany the decisive factors that led to the creation of the integrated supervisory authority are the following: ${ }^{3}$

The integration of financial sectors leads to the blurring of borders between banking, insurance and securities. Customers increasingly demand comprehensive financial services. Providers have adjusted to these necessities by developing Allfinanz-strategies and Allfinanz-products. Thus, banks, insurance companies and securities firms are increasingly competing for the same clients with similar or often identical products.

Convergence of products of banking, insurance and securities firms is particularly advanced with respect to mortgage credits, and asset management.

The blurring of borders between financial products is further pushed ahead by the reform of pension systems. In Germany - as in many other European countries - the traditional pay-as-you-go pension systems are increasingly replaced by occupational and private pension plans. In this context banks, insurance firms and other financial services providers are more and more offering a variety of cross-sectoral products (e.g., fund-based life insurance).

There is also convergence with respect to the distribution of products. Insurers make use of the distribution channels of banks and vice versa. Moreover, the new information and communication technologies, such as the internet, make it easy to dismantle the traditional value-added chain of financial services. A

\footnotetext{
${ }^{3}$ See, e.g., Bundesministerium der Finanzen (2001), Börsen-Zeitung (2001a), BaFin (2004).
} 
mortgage credit contract, for example, doesn't have to be placed over the bank counter.

The co-operation of financial institutions has also lead to the formation of financial conglomerates, i.e. groups of companies with a common strategy and a central management structure, offering a wide spectrum of one-stop financial products. ${ }^{4}$ Although a major financial conglomerate hadn't emerged by the time Finance Minister Eichel announced the plans to integrate supervision, this changed rapidly in Mai 2001 with the merger of the biggest German insurance company Allianz and Dresdner Bank - the third-biggest bank in Germany at that time.

In addition to these arguments based on the increasing importance of Allfinanz, an often cited advantage of the new arrangements for financial supervision is that it will boost the competitiveness of Germany as a financial centre, since efficient and effective financial supervision can be regarded as a location factor (vision+money, 2002). For all market participants it will be easier to deal with a single regulator instead of three separate agencies. Moreover, co-operation with supervisory bodies abroad is simplified, and the "voice of the German federal regulator will carry more weight in international negotiations over financial regulations” (BaFin, 2003).

Finally, there are the well-known arguments of economies of scale and scope, and preventing regulatory arbitrage.

With respect to the development towards establishing a European framework for financial supervision, Finance Minister Eichel emphasised that the creation of the single German financial supervisor doesn't block any EU-wide supervisory concept (Bundesministerium der Finanzen, 2001). Eichel argued that the new integrated structure may even be seen as a promoter for a European supervisory system.

\section{Allfinanz in the German Financial Market}

As was outlined in the previous section, the main rationale for the creation of the integrated financial supervisory authority in Germany was - as in most other countries - the blurring of borders between banks, insurers and financial services providers. The increasing importance of Allfinanz requires unification of supervisory functions. This section looks at the importance of Allfinanz in the

\footnotetext{
${ }^{4}$ We will differentiate the notions financial conglomerate, Allfinanz, and Bancassurance in the next section.
} 
German financial market. Beforehand, we define and differentiate the notions Allfinanz, bancassurance and financial conglomerates.

\section{Allfinanz, Bancassurance, and Financial Conglomerates}

In this paper we define Allfinanz as a more general notion that includes any development towards offering one-stop financial services (Börner, 2000). In Germany Allfinanz is usually understood as offering a wide range of financial products comprising banking and insurance products. Allfinanz concepts may take different forms, such as distribution agreements, joint ventures, crossshareholding, mergers and acquisitions, and internal development.

Because most references of convergence at the distribution level have been to bank-insurance linkages, the French term bancassurance is often used. In the original sense it refers merely to the distribution of insurance products via the bank channel (Lumpkin, 2002: 7; Benoist, 2002). It is, however, often used in a more broader sense for the involvement of banks, in the manufacturing, marketing or distribution of insurance products (Wolgast, 2002). In contrast, the term assurfinance refers to a similar situation in which an insurance company sells savings products (Lumpkin, 2002; Benoist, 2002).

Allfinanz and bancassurance are thus rather general concepts describing financial convergence, i.e. various kinds of interfaces (with or without capital ties) between different categories of financial services providers - usually between banks and insurers.

The label financial conglomerate is used for corporate groups with a common strategy and a central management structure, offering a wide spectrum of onestop financial products (Bundesministerium der Finanzen, 2001). Some authors use the notion for groups of companies that provide significant services in at least two different financial sectors (Abrams and Taylor, 2002; Group of Ten, 2001). Others in contrast use it for groups that combine banking, securities, and insurance activities within one organisation (Lelyveld and Schilder, 2002; Lumpkin, 2002). In the light of the universal bank structure which characterises Germany as well as many other continental European countries, the latter definition seems to be more appropriate.

In Germany, banks have traditionally been free to operate as universal banks, i.e. to undertake a full range of securities activities. Thus, most (at least bigger) banks typically combine commercial banking and investment banking activities. Consequently, one could think of German (and most continental European) banks as financial conglomerates when using the notion for groups that provide significant services in at least two financial sectors. In the context of integrated 
financial supervision it is therefore reasonable to consider groups as financial conglomerates that combine universal banking and insurance activities.

The primary motive for financial consolidation is the realisation of economies of scale and scope with respect to, e.g., the distribution and marketing of products, back office activities or asset management. ${ }^{5}$ This allows for costs savings and revenue enhancements. Cross-selling of products becomes possible, and the offering of combinations of bank and insurance products, e.g., in the context of the current pension reform.

\section{The Importance of Allfinanz in the German Financial Sector}

As mentioned above, a major financial conglomerate hadn't emerged in Germany before the acquisition of Dresdner Bank by Allianz in Mai 2001. However, Germany had a tradition of cross-shareholding between banks and insurance companies. For example, Munich Re, the world's biggest reinsurance firm and Germany's second-biggest primary insurer owns about one-quarter of HypoVereinsbank, Germany's second biggest bank. Thus, collaboration between banks and insurance companies has always been quite important, although in Germany besides Allianz/Dresdner no major financial conglomerate has emerged.

\footnotetext{
${ }^{5}$ For the advantages as well as the disadvantages of forming a financial conglomerate, see, e.g., Wolgast (2001, 2002), EU Commission (2001), Brixner (2002), Börner (2000), Benoist (2002).
} 
Figure 1: Cross-Sector M\&As in the German Financial Sector

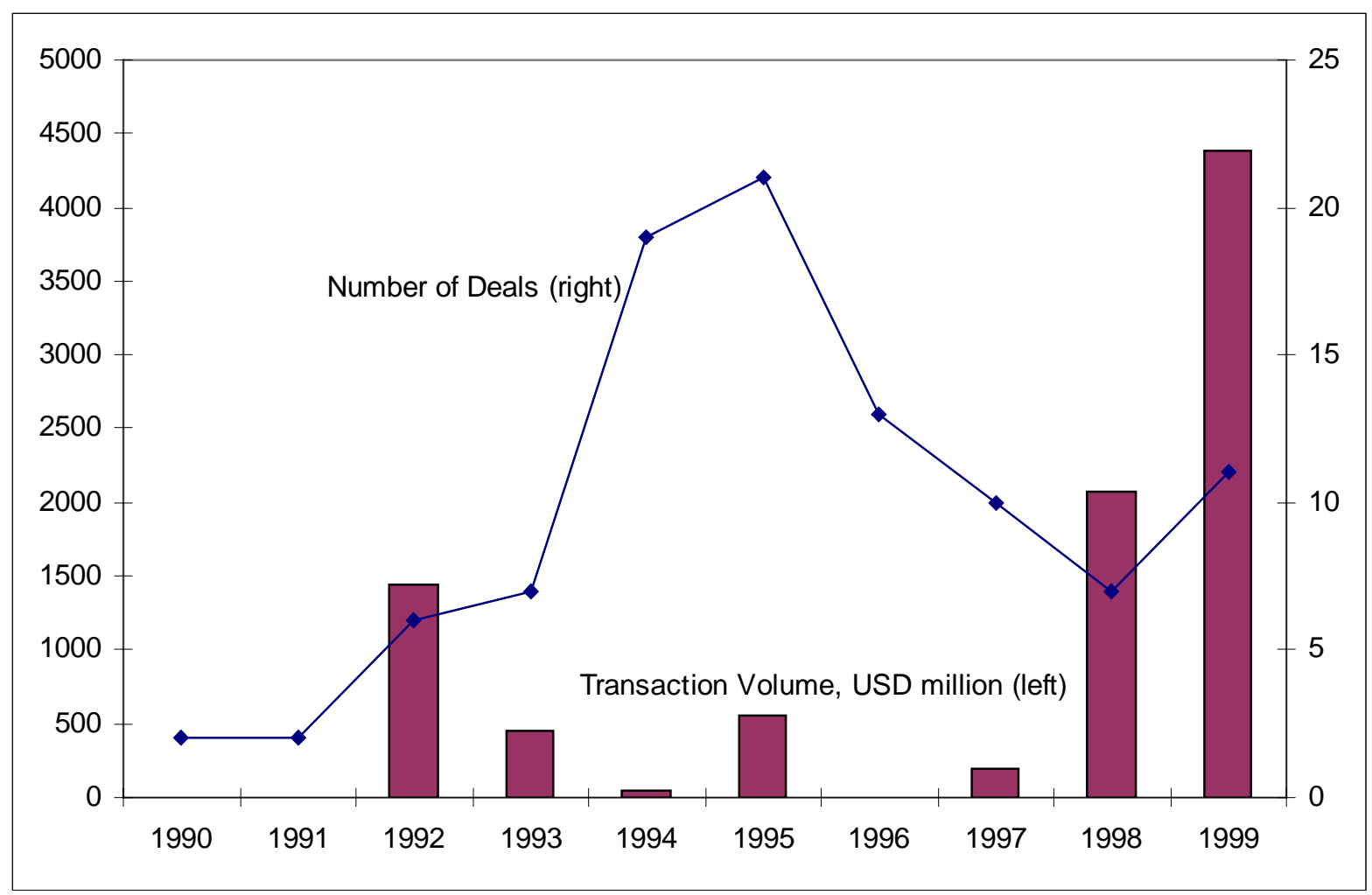

Source: Group of Ten (2001); Note: Included are all mergers or acquisitions of majority interest, i.e. the acquirer's ownership share of the target exceeded $50 \%$ as a result of the transaction. Deals classified by sector and country of the target firm.

Figure 1 shows cross-sector mergers and acquisitions (M\&As) in the German financial sector over the years 1990-99. After having increased between 1990 and 1995, the number of deals has fallen until 1998. However, total transaction volume has sharply increased in 1998 and again in 1999. 
Figure 2: Total Transaction Volume of Cross-Sector M\&As in the Financial Industry as Percent of GDP

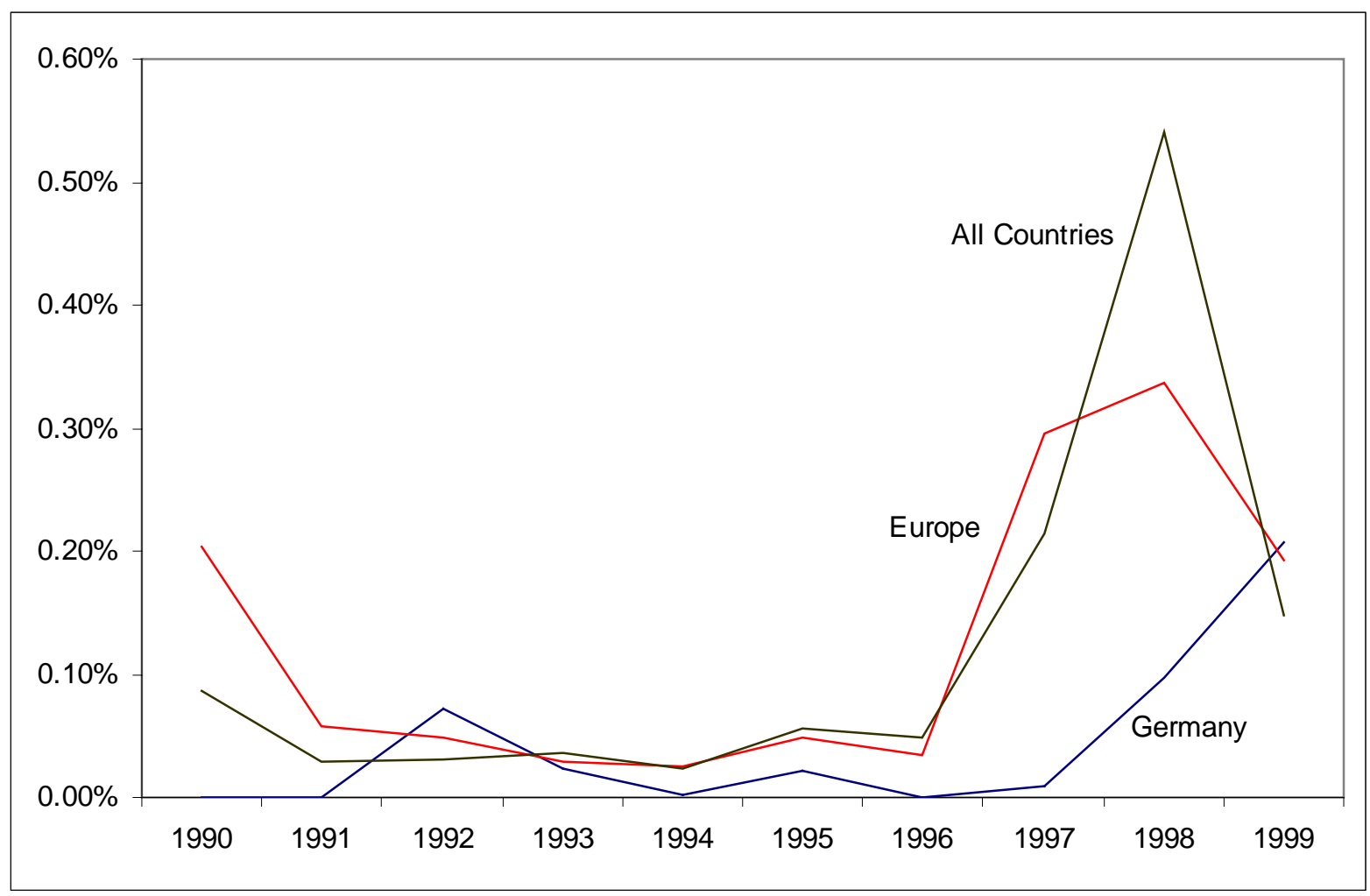

Source: Group of Ten (2001); Note: Included are all mergers or acquisitions of majority interest, i.e. the acquirer's ownership share of the target exceeded $50 \%$ as a result of the transaction. Deals classified by sector and country of the target firm.

Figure 2 compares total transaction volumes of cross-sector M\&As in Germany with all European and all other countries. ${ }^{6}$ Cross-sector M\&A volume in Germany as a percent of GDP has been relatively low compared to other countries until 1998. Only the figure for 1999 reaches the size of the other countries.

${ }^{6}$ Included in the sample are the United States, Canada, Japan, Australia, Belgium, France, Germany, Italy, the Netherlands, Spain, Sweden, Switzerland, and the United Kingdom. 
Figure 3: Shares of Cross-Sector M\&A deals as Percent of Total Deals in the Financial Industry

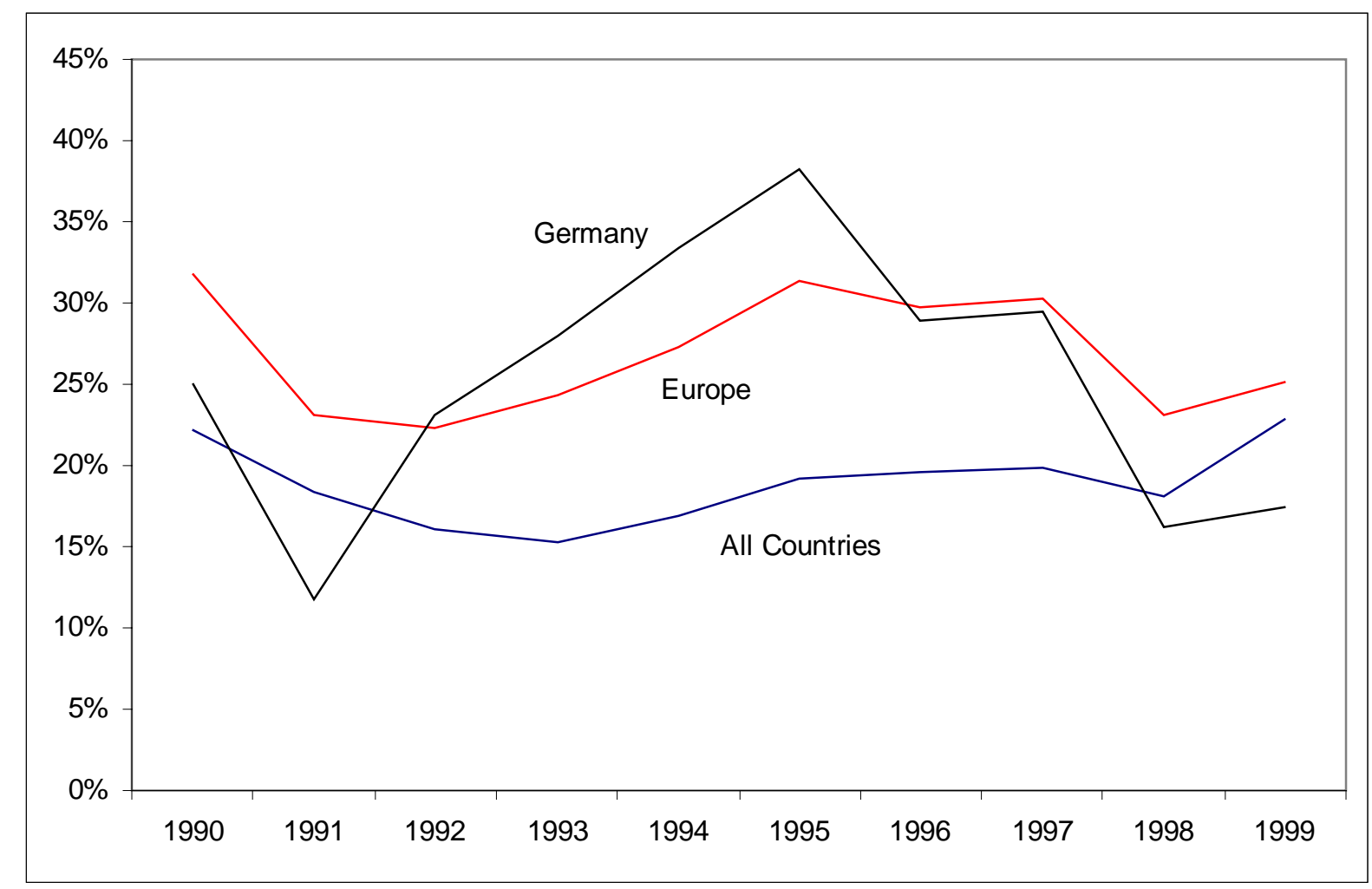

Source: Group of Ten (2001); Note: Included are all mergers or acquisitions of majority interest, i.e. the acquirer's ownership share of the target exceeded $50 \%$ as a result of the transaction. Deals classified by sector and country of the target firm.

However, when looking at shares of cross-sector M\&A deals as a percentage of total M\&A deals in the financial industry, Germany lies mostly above the other countries (Figure 3).

Figure 4 shows data for the market shares that financial conglomerates have in the national banking and insurance markets, respectively. In Germany financial conglomerates have relatively little stakes in the financial markets as compared with other European countries. In banking 17\% of bank deposits can be assigned to financial conglomerates, which compares to a $27 \%$ for the total EU. As compared to banking, financial conglomerates have more stakes in the German insurance markets: $30 \%$ of total life insurance premium income and $29 \%$ of total non-life insurance premium income can be assigned to conglomerates. This is above the numbers for the total EU, where conglomerates are responsible for $27 \%$ of life and $19 \%$ of non-life premium income. Thus, financial conglomerates in Germany are of lower importance than in other European countries, in particular Belgium and Finland. However, the market share of financial conglomerates in the German financial markets is quite significant, particularly in insurance. 
Figure 4: Market Shares of Financial Conglomerates in the National Banking/Insurance Market

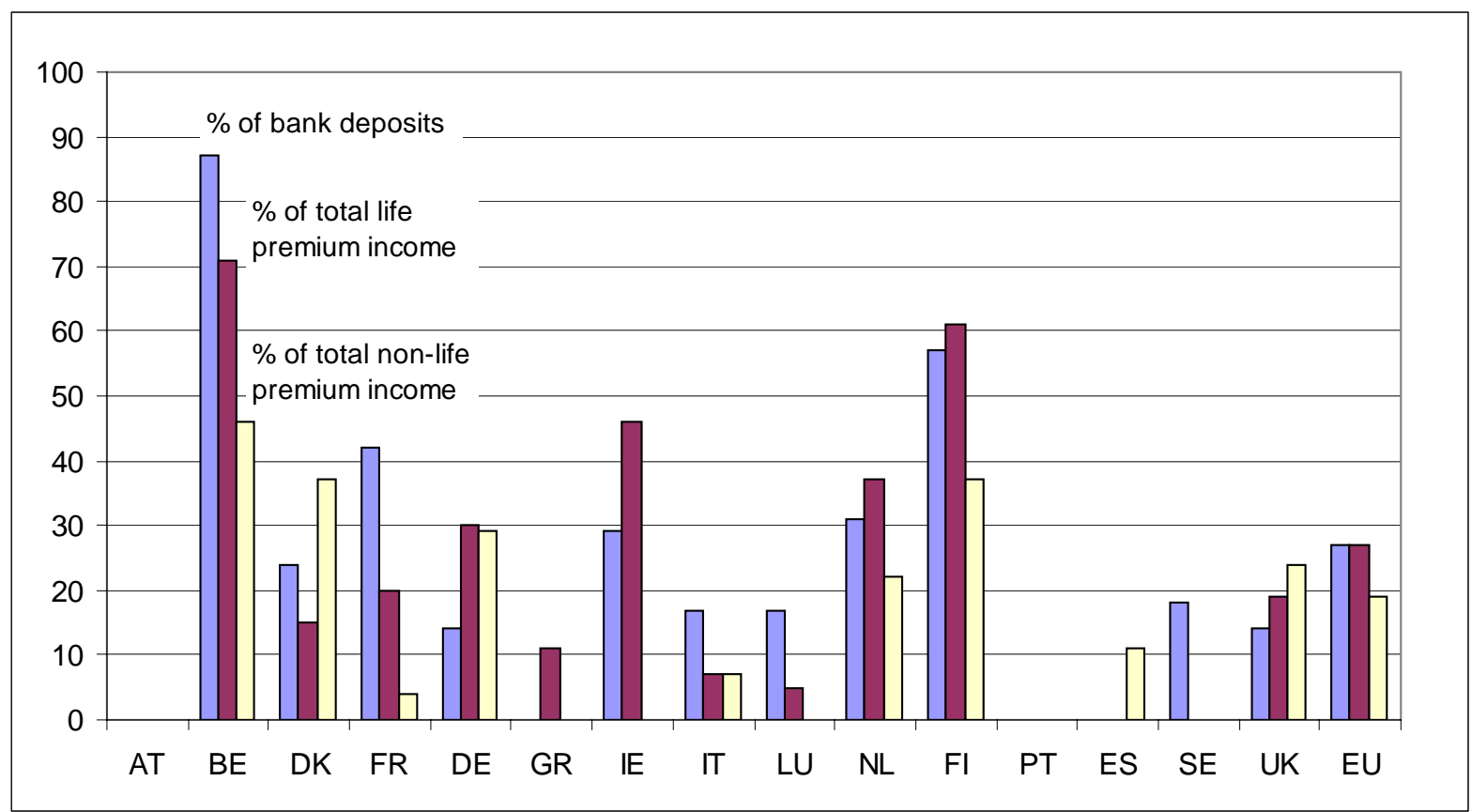

Source: Smith (2003). Note: data refers to the year 2001; AT: Austria, BE: Belgium, DK: Denmark, FR: France, DE: Germany, GR: Greece, IE: Ireland, IT: Italy, LU: Luxembourg, NL: The Netherlands, FI: Finland, PT: Portugal, ES: Spain, SE: Sweden, UK: United Kingdom, EU: EU average.

As mentioned above, financial consolidation is just one aspect of Allfinanz. Convergence with respect to the distribution of financial products is another important aspect.

Figure 5 shows shares of distribution channels of insurance as measured by total volume of new business. The most important distribution channel is the one via single tied agents which accounts for about 60 percent of the new insurance business in 2000 and 2001. Multiple intermediaries account for about 20 percent of new business. Distribution via the bank counter is still of minor importance: only 9.6 percent in 2000, and an even smaller 8.9 percent in 2001, were distributed via banks. 
Figure 5: Shares of Distribution Channels of Insurance in Germany as Measured by the Volume of Total New Business (in Percent)

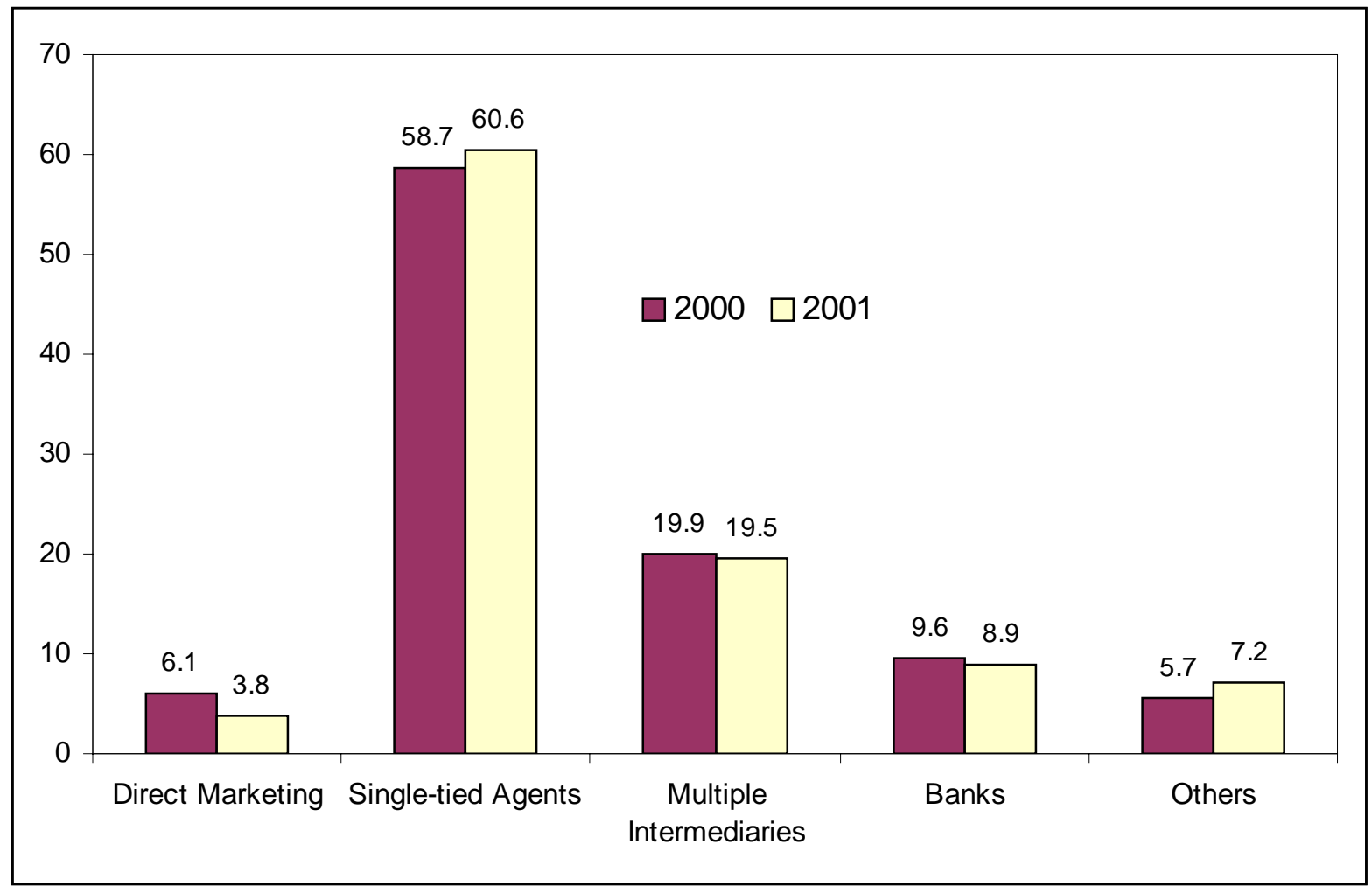

Source: German Insurance Association (GDV).

Overall, one could conclude from the presented data that Allfinanz is still not very important for the German financial market, and that therefore the creation of an integrated supervisory authority may not have been necessary from this perspective. However, there are many other important aspects of Allfinanz that are difficult to capture. The blurring of boundaries with respect to products being just one example. In the course of the pension reform new hybrid products gain increasingly importance. Another example is the rapid development of credit derivatives that are used by banks and other institutions to limit risk concentrations in their portfolios. Clearly, such products are a useful contribution to the efficient redistribution of risk. Many of the risks are on-sold by banks and find their way into the portfolio of insurance companies (Crockett, 2001). Thereby banks and insurance companies are closely connected through risk exposure without any formal co-operation.

Thus, at the end of the day Allfinanz might play quite a significant role in the German financial market - even today, and it clearly is gaining in importance. 


\section{BaFin - The New Single Supervisor}

\section{Formation of the Single Supervisory Authority}

A reform of the supervision of the German financial markets was announced on January 25, 2001 by Hans Eichel, the German finance minister. He proposed the creation of a new Federal Authority for Financial Services Supervision with the responsibility for the supervision of credit institutions, insurance companies, investment firms and other financial institutions. The plan of consolidating financial market supervision was accompanied by a proposal to restructure the German Bundesbank. By proposing a central management structure Eichel wanted to secure a more efficient representation of the Bundesbank in the decision-making process of the European Central Bank (ECB). Eichel's proposal was followed by a heated public debate. At first, it was fiercely opposed by the federal states (Länder), the Bundesbank and also the ECB (FAZ, 2001).

Ever since the introduction of the euro - when the national central banks lost their monetary policy function - the federal government and the federal states argued about the structure of the Bundesbank. So even before the plan of consolidating supervision was announced, the Bundesbank's leadership had been carrying out a public campaign to become the sole banking supervisor by integrating the banking supervisory agency, BAKred, into a department of the Bundesbank (Engelen, 2001). By such a move the Bundesbank would have been compensated for the loss of responsibility for monetary policy. The Bundesbank had been already heavily involved in banking supervision through the support service it had provided to the BAKred. They argued that without strengthening the role of the Bundesbank as a banking supervisor, it would lose influence in the European System of Central Banks (ESCB) as many other central banks in Euroland are responsible for banking supervision. Therefore, in fear of further losing competencies the Bundesbank fiercely opposed Eichel's plan to merge the separated supervisors into a single agency.

In the end, however, the Bundesbank, lacking broad support from the Länder, couldn't achieve its plans to become the sole banking supervisor and supported Eichel's plans. This move was also based on the fact that Eichel ceded ground and guaranteed the Bundesbank and the regional branches of the Bundesbank (Landeszentralbanken) an ongoing strong role in banking supervision (BörsenZeitung, 2001b). Thereby Eichel responded also to a statement by the $\mathrm{ECB}^{7}$ that warned against taking away prudential supervision from the central bank. The Länder finally also supported Eichel's plans - which in the light of their

\footnotetext{
${ }^{7}$ ECB (2001).
} 
influence on legislation through the Bundesrat (the upper house of the German parliament) was of crucial importance. ${ }^{8}$

On March 22, 2002 the bill on restructuring financial supervision was ultimately passed and on May 1, 2002 the new single regulator, Bundesanstalt für Finanzdienstleistungssaufsicht (BaFin), started operating based on the law on a single financial services supervisory authority (Gesetz über die integrierte Finanzdienstleistungsaufsicht).

\section{Objectives, Responsibilities and Scope of Supervisory Powers}

The overall objective of the BaFin is to ensure the stability and integrity of the German financial system as a whole. The two resulting objectives are: safeguarding the solvency of banks, financial services providers and insurance companies; and protection of consumers and investors. Thus, the BaFin is a single regulator in the sense that it combines both prudential and conduct of business aspects. ${ }^{9}$

The BaFin's responsibilities cover the supervision of the widest range of financial institutions, including credit institutions, insurance companies, other financial institutions and securities markets. It combines the responsibilities of the hitherto existing sectoral supervisory agencies: The Bundesaufsichtsamt für das Kreditwesen (BAKred) that was responsible - in co-operation with the Bundesbank - for supervising banks; the Bundesaufsichtsamt für das Versicherungswesen (BAV) that regulated insurance companies; and the Bundesaufsichtsamt für den Wertpapierhandel (BAWe) that was in charge of securities activities at the federal level. Exchange supervision remains, by contrast, in the jurisdiction of the federal states.

\section{Internal Organisation}

BaFin is chaired by a President and a Deputy President with the support of three Chief Executive Directors heading the three core directorates for supervision of banking, insurance, and securities/asset management (see Figure 6 for an organisation chart). These core directorates largely correspond to the three former supervisory agencies - minus the collective tasks common to all three areas that are now handled by cross-sectoral departments. The Banking Supervision directorate has been assigned all regulatory powers as regards

\footnotetext{
${ }^{8}$ The Länder could have blocked the bill with a 2/3-majority in the Bundesrat.

${ }^{9}$ Another so called functional approach is to have separate agencies for prudential and conduct of business supervision. For example, the Netherlands have adopted such an approach.
} 
solvency-oriented supervision of credit institutions. The Insurance Supervision directorate is responsible for insurance undertakings both in terms of solvency and conformity with legislative requirements. The directorate Securities/Asset Management is in charge of regulating the respective markets in accordance with the Securities Trading Act (Wertpapierhandelsgesetz - WpHG) and the Securities Acquisition and Takeover Act (Wertpapiererwerbs- und Übernahmegesetz - WpÜG). This pillar organisation ensures that sector specific peculiarities are taken into account, which is necessary since the underlying regulation hasn't changed.

\section{Figure 6: Organisation of BaFin}

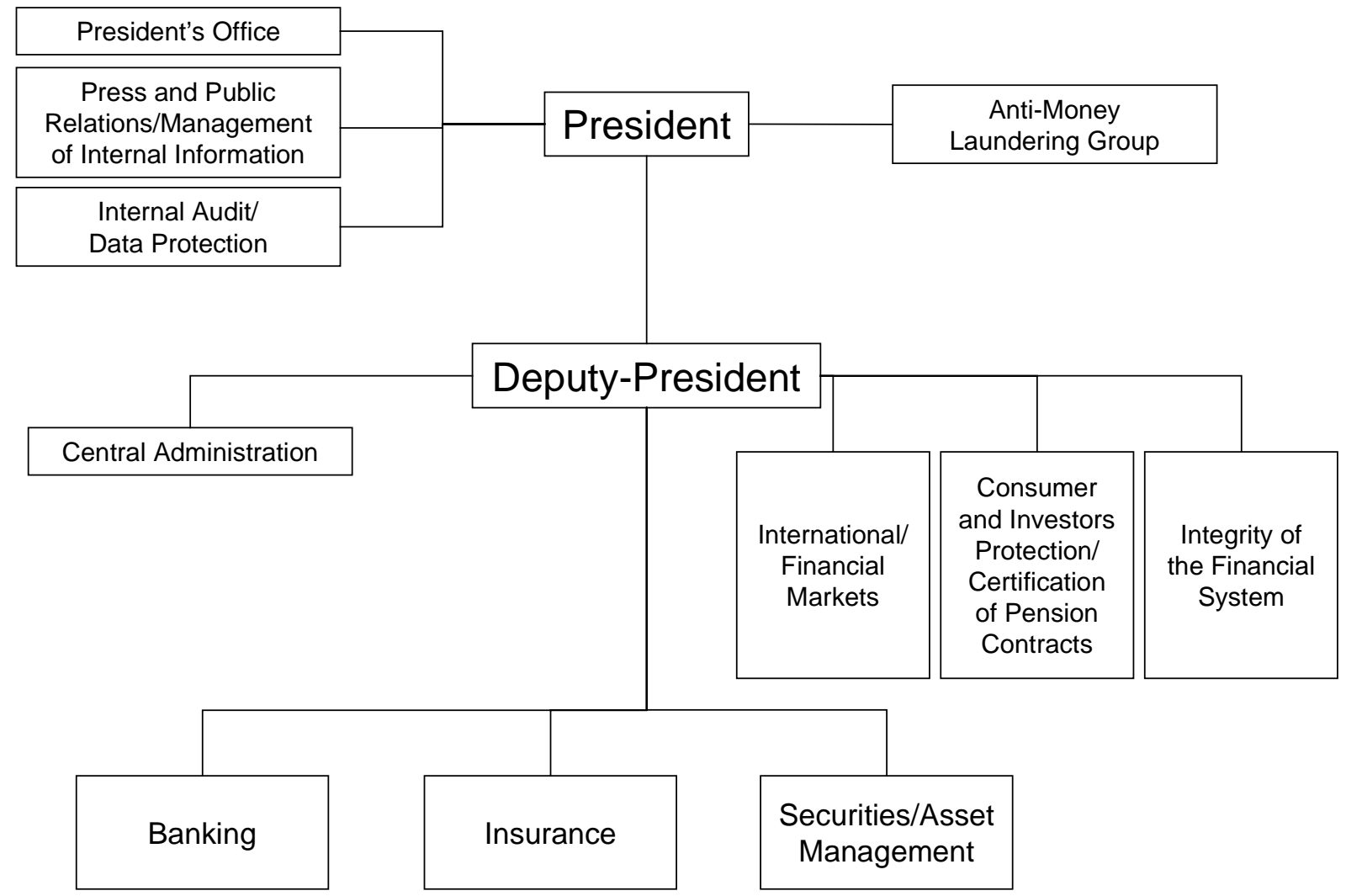

To maximise the synergies and to deal with issues affecting all directorates, three cross-sectoral departments were created:

- The department International/Financial Markets deals with the supervision of financial conglomerates, reporting and disclosure of banking and insurance companies, as well as with fundamental supervisory issues related to national and international financial markets. The department includes also tasks with respect to the co-operation of the BaFin in international supervisory committees, such as the Basel committee and the various European committees. 
- The department Consumer and Investors Protection/Certification of Pension Contracts deals with fundamental issues of consumer protection as well as with specific consumer complaints concerning banks, financial institutions and insurers. In addition, this department is in charge of the certification of pension contracts and retirement schemes.

- The department Integrity of the Financial System deals with fundamental and legal questions concerning the prosecution of illegal banking, financial services and insurance practices.

The core directorates and the cross-sectoral departments, as well as the Central Administration unit, responsible for personnel, organisation, information technology and the budget, report to the Deputy President.

In addition there are four staff units directly reporting to the President: the President's Office; Press and Public Relations/Management of Internal Information; the Internal Audit/Data Protection unit; and the Anti-Money Laundering group.

BaFin is based in Bonn and Frankfurt, as the BAKred and the BAV were located in Bonn and the BAWe in Frankfurt. ${ }^{10}$

By late 2002 there were 1,277 positions at BaFin: 468.5 positions fell into the upper executive level, 464 were senior management roles, 284.5 were in middle management, and 60 at the junior public service level.

\section{Supervision of Financial Conglomerates}

The internal organisation of the BaFin continues to preserve the distinction between banking, insurance and securities supervision as separate operational divisions within the integrated agency. Although there are three cross-sectoral departments that deal with issues relating to all financial sectors, there exists no separate division for the supervision of financial conglomerates. Only a subdivision to the cross-sectoral department International/Financial Markets deals explicitly with the supervision of financial conglomerates.

As mentioned above, this pillar organisation ensures that sector specific differences are taken into account. Moreover, it has the virtue of simplicity. However, it is not very suitable for improving communication when it comes to supervising financial conglomerates (Taylor and Fleming, 1999a, b).

10 This straddle may be not optimal, since the majority of banks in Germany are headquartered in Frankfurt (vision+money, 2002). The Bundesbank which is strongly involved in banking supervision is, however, located in Frankfurt. 
Another impediment in this respect is the fact that the underlying regulation hasn't changed (BaFin, 2004, 2002). There was a new law passed on a single financial services supervisory authority (Gesetz über die integrierte Finanzdienstleistungsaufsicht) which builds the basis for BaFin. However, BaFin is still working mostly with legislation inherited from its predecessor organisations. With respect to banking supervision this is primarily the Kreditwesengesetz (KWG); with respect to insurance supervision the Versicherungsaufsichtsgesetz (VAG); and with respect to securities/asset management the Wertpapierhandelsgesetz (WpHG). There exists no single, coherent financial services statute under which conglomerates can be regulated. Therefore, it could be difficult to deliver some of the alleged benefits of an integrated approach to supervision of financial conglomerates.

According to Taylor and Fleming (1999a, b) this problem applies to most of the recently established integrated supervisory authorities. An alternative would be to organise the integrated agency along more "functional" lines, by, e.g., distinguishing between larger, systematically important institutions and smaller, non-systemic institutions. However, this may result in a complex internal matrix management structure.

Although financial conglomerates haven't been of major importance for the German financial market in the past, the merger of Allianz and Dresdner Bank has - at least partly - changed this picture. ${ }^{11}$ Besides, the apparent integration of financial sectors, e.g., with respect to products and distribution channels, makes a truly integrated supervisory structure also important. Whether the newly created cross-sectoral departments supplementing the pillar structure of the BaFin are sufficient has to be seen in the future.

Another potential problem of preserving the distinction between banking, insurance and securities supervision as separate operational divisions may be a tendency to preserve also existing institutional cultures, thereby inhibiting the authority's ability to function as a single integrated entity (Taylor and Fleming, 1999a). Certainly, it is too early to say whether such a problem is present in the case of the BaFin.

\section{Governance}

BaFin is subject to legal and supervisory control of the Ministry of Finance, but it is a functionally and organisationally independent body (IMF, 2003). Although the Ministry of Finance could in principle issue instructions on a range

${ }^{11}$ As mentioned in Section 2, the decision in January 2001 to integrate supervision wasn't mainly justified by the need to respond to the formation of financial conglomerates. 
of organisational and other matters, in practice it does not interfere in supervisory matters.

The management of BaFin is monitored by an Administrative Council. It comprises 21 representatives coming from the Federal Ministry of Finance (4 including the chairman), the Federal Ministry of Economics and Labour (1), the Federal Ministry of Justice (1), the Parliament (5), and the financial industry (10), i.e. the companies BaFin supervises.

Moreover, an Advisory Board advises BaFin on how to carry out its specific tasks. It is composed of 24 members from the banking and insurance industry, consumer protection associations, academic institutes, and the German Bundesbank.

\section{Funding}

Before the unification of supervision 10 percent of the budgets (in 1999 some EUR 6.9 million) of the three supervisory agencies were funded by the federal government (vision+money, 2002). The newly established single supervisor is now completely financed by levies and fees paid by the supervised organisations; thus, BaFin receives no funding from the federal budget (BaFin, 2003). ${ }^{12}$ In addition to contributions by the regulated companies, BaFin charges fees for certain services. In 2003 (2004) total budget for income and expenses was set at EUR 118.8 (132.5) million. The 2003 (2004) income was generated from advanced payments of allocation of costs of EUR 106.8 (120.7) million and service fees of EUR 11.9 (11.7) million.

\section{The Involvement of the Bundesbank}

The decision to create an integrated supervisory agency also raises the issue of the involvement of the central bank. In this respect Germany may be regarded as a special case among the countries that have adopted a single supervisory agency, since the Bundesbank plays a significant role in banking supervision (Sanio, 2003). ${ }^{13}$

The pros and cons of the involvement of the central bank in banking supervision are well-known. ${ }^{14}$ In the German context it was argued that the often cited

\footnotetext{
12 The Bundesbank pays for its own banking supervisory effort.

13 With respect to the relationship between central banking and integrated financial supervision, Masciandaro (2004) finds that most countries with a high level of unification of supervisory powers exhibit weak central bank involvement in supervision.

${ }^{14}$ See, e.g., Goodhart and Schoenmaker (1993, 1995), Haubrich (1996), ECB (2001).
} 
argument against central bank involvement, namely a potential conflict of interest between supervision and monetary policy, has lost validity as the national central banks are no longer in charge of monetary policy.

After having lost its monetary policy powers the Bundesbank would have liked to integrate the banking supervisory agency BAKred and become Germany's single bank supervisor. The pleading of prominent central bankers was supported by some academics (Kösters et al., 2001) stating that economies of scope resulting form the joint execution of monetary and supervisory tasks can only be realised with a central bank solution. With the establishment of the BaFin the plans of central bankers to integrate the supervisory authority into the Bundesbank were shattered.

The Bundesbank remains, however, highly involved in the supervision of banks. ${ }^{15}$ The co-operation between BaFin and Bundesbank is regulated by Artikel 7 of the Banking Act (Kreditwesengesetz - KWG); details are outlined in a Memorandum of Understanding.

The BaFin remains, as was the BAKred, the only decision making authority with respect to the supervision of credit institutions, investment firms and other financial institutions regulated by the banking act (Sanio, 2003). The involvement of the Bundesbank in the prudential supervision applies in practice mostly to the day-to-day supervision of banks. In this respect there is close cooperation between the BaFin and the regional representations of the Bundesbank. This "ongoing supervision" of banks and financial institutions comprises off-site activities, such as the analysis of submitted documents, annual reports and auditor's reports, as well as on-site examinations to assess, e.g., the capital adequacy and the risk management measures of the institutions. Moreover, to the extent legally possible, BaFin is now enabled to base its supervisory decisions on the assessments and findings by the Bundesbank. Overall, the new arrangements are expected to avoid double work and increase the effectiveness of day-to-day banking supervision (Sanio, 2003).

The Forum for Financial Market Supervision (Forum für Finanzmarktaufsicht) co-ordinates collaborative work conducted by BaFin and the Bundesbank. It is set up within BaFin and jointly run by BaFin and the Bundesbank. Thereby meetings between high-ranking representatives from both institutions are formalised. It also provides advice on supervisory issues that are significant to the stability of the financial system. This includes also issues with regard to integrated supervision. By establishing this forum, the BaFin and the

${ }^{15}$ Some say that the Bundesbank ended up having even greater powers in banking supervision than before (Börsen-Zeitung, 2002; vision+money, 2002). 
Bundesbank are acknowledged as the authorities jointly responsible for the stability of the financial system.

\section{Conclusion}

With the establishment of the Bundesanstalt für Finanzdienstleistungsaufsicht (BaFin) in May 2002, Germany followed the trend towards integrated financial supervision. Among the countries having adopted a single supervisory authority Germany may be regarded as special since the Bundesbank remains strongly involved in banking supervision.

The main argument in favour of unification of supervisory functions is that financial sectors become more and more integrated, thus, blurring the boundaries between banking, insurance and securities activities. Although, in Germany financial conglomerates have been only of minor importance, the acquisition of Dresdner Bank by Allianz has created a significant Allfinanz group. Moreover, developments such as the reform of pension systems increasingly induce that products are being offered that combine banking and insurance products.

The creation of BaFin merged the hitherto separated supervisory agencies for banking, insurance and securities, which is reflected in the pillar organisation of the new single authority. Three cross-sectoral departments deal with issues relating to all financial sectors. Whether this organisational structure inhibits BaFin's ability to function as a single integrated entity and deliver the benefits of an integrated supervisory approach has to be seen in the future. 


\section{References}

Abrams, R.K. and M.W. Taylor (2000), Issues in the Unification of Financial Sector Supervision, IMF Working Paper 213, December 2000.

Abrams, R.K. and M.W. Taylor (2002), Assessing the case for unified Financial Sector Supervision, London School of Economics Financial Market Group Special Paper 134.

Australian Prudential Regulation Authority (2000), Harmonising Prudential Standards: A Principles-Based Approach, Policy Discussion Paper December 2000.

BaFin (2004), Aufgaben \& \&iele, http://www.bafin.de/bafin/aufgabenundziele.htm, as of 12 January 2004.

BaFin (2003), Annual Report 2002 Bundesanstalt für Finanzdiensleistungsaufsicht Part A, June 2003, Bonn/Frankfurt.

BaFin (2002), Bundesanstalt für Finanzdiensleistungsaufsicht, Startschuss für die Allfinanzaufsicht in Deutschland, Statement to the Press, 29 April 2002, Bonn/Frankfurt.

Benoist, G. (2002), Bancassurance: The New Challenges, The Geneva Papers on Risk and Insurance 27 (3), 295-303.

Börner, C. (2000), Allfinanz, neue Bankvertriebswege und Resource-based View, Mitteilungen und Berichte des Instituts für Bankwirtschaft und Bankrecht an der Universität zu Köln, 31. Jahrgang, Nr. 83.

Börsen-Zeitung (2001a), Allfinanz stärkt hiesigen Finanzplatz, Börsen-Zeitung, 26 January 2001, p.20.

Börsen-Zeitung (2001b), Eichel lenkt im Streit mit Bundesbank ein, BörsenZeitung, 29 May 2001, p.1.

Börsen-Zeitung (2002), "Neue Aufsicht stärkt die Wettbewerbsfähigkeit des Finanzplatzes”, Börsen-Zeitung, 11 April 2002.

Briault , C. (1999), The Rationale for a Single National Financial Services Regulator, FSA Occasional Paper Series No. 2, London.

Briault , C. (2002), Revisiting the rational for a single national financial services regulator, FSA Occasional Paper Series No. 16, London.

Brixner, U. (2002), Die Zukunft des Finanzsektors: Rücken Banken und Versicherungen zusammen?, Keynote Speech at the 9th Symposium on Finance, Banking, and Insurance, 11 December 2002, Karlsruhe.

Bundesministerium der Finanzen (2001), Allfinanzaufsicht und Bundesbankreform stärken Finanzplatz Deutschland, Statement to the Press, 25 January 2001. 
Crockett, A. (2001), The Regulation of Financial Services: International Principles and Standards, Speech at the 17th International PROGRESS Conference, 13 September 2001, Geneva.

Engelen, K. (2001), Eichel's shock to the system, The Financial Regulator 5 (4), 38-42.

European Central Bank (2001), The role of central banks in prudential supervision, March 2001, Frankfurt.

EU Commission (2001), Verordnung (EWG) Nr. 4064/89 über Fusionsverfahren, Fall Nr. COMP/M.2431 - Allianz/Dresdner, 19.07.2001, Brussels.

FAZ (2001), Meister: Reform schwächt Bundesbank, Frankfurter Allgemeine Zeitung, 27 January 2001, p.13.

Goodhart, C. and D. Schoenmaker (1993), Institutional Separation between Supervisory and Monetary Agencies, LSE Financial Market Group, Special Paper No. 52.

Goodhart, C. and D. Schoenmaker (1995), Should the Functions of Monetary Policy and Banking Supervision be separated?, Oxford Economic Papers 47 (4), 539-560.

Group of Ten (2001), Report on Consolidation in the Financial Sector, January 2001.

Haubrich, J.G. (1996), Combining Bank Supervision and Monetary Policy, Federal Reserve Bank of Cleveland Economic Commentary Series, November 1996.

International Monetary Fund (2003), Germany: Financial System Stability Assessment, IMF County Report No. 03/343, November 2003, Washington D.C.

Kösters, W., S. Paul and J. Süchting (2001), Ein Effizienzmodell zur Strukturreform der Deutschen Bundesbank, Zeitschrift für das gesamte Kreditwesen, 1. Mai 2001.

Lelyveld, I. van and A. Schilder (2002), Risk in Financial Conglomerates: Management and Supervision, Paper to be presented at the Joint USNetherlands Roundtable on Financial Services Conglomerates, 24-25 October 2002, Washington D.C.

Lumpkin, S. (2002), Supervision of Financial Services in the OECD Area, OECD Financial Market Trends, No. 81, Paris.

Luna Martínez, J. de and T.A. Rose (2003), International Survey of Integrated Financial Sector Supervision, World Bank Policy Research Working Paper 3096, July 2003. 
Masciandaro, D. (2004), Unification in Financial Sector Supervision: The Trade-off Between Central Bank and Single Authority, forthcoming in Journal of Financial Regulation and Compliance 12 (2).

Sanio, J. (2003), The new Single Regulator in Germany, in Kuppens, T., H. Prast, and S. Welleling (eds.), Banking Supervision at the Crossroads, Edward Elgar, Cheltenham, 55-58.

Smith, P. (2003), The Financial Conglomerates Directive - Progress Towards Implementation, Presentation at the 4th Seminar on "EU Banking and Financial Law" at the EIPA, 6-7 October 2003, Maastricht.

Taylor, M. and A. Fleming (1999a), Integrated Financial Supervision. Lessons of Scandinavian Experience, Policy Research Working Paper, World Bank, Washington.

Taylor, M. and A. Fleming (1999b), Integrated Financial Supervision. Lessons of Scandinavian Experience, Finance \& Development (December), 42-45.

vision+money (2002), Supervision is not Divisible, vision+money 22 (April), The Financial Markets Magazine of Deutsche Börse AG, 11-17.

Wolgast, M. (2001), M\&As in the financial industry: A mater of concern for bank supervisors?, Journal of Financial Regulation and Compliance 9 (3), 225-236.

Wolgast, M. (2002), The Economic Virtues of Bancassurance: Fact or Fiction, Études et Dossiers, Working Paper Series of the Geneva Association, No. 254, March 2002, 6-18. 